\title{
Evidence based road safety? The Driving Standards Agency's schools programme
}

\author{
Contributors (names listed alphabetically) \\ Shirley Achara \\ Bola Adeyemi \\ Efunbo Dosekun \\ Suzanne Kelleher \\ Marilyn Lansley \\ Ian Male \\ Nermin Muhialdin \\ Lucy Reynolds \\ lan Roberts \\ Mirsada Smailbegovic \\ Nick van der Spek
}

\section{Cochrane Injuries Group Driver Education Reviewers}

\section{Introduction}

In March 2000, the British Government launched its road safety strategy, setting out how it plans to achieve a $40 \%$ reduction in road deaths and serious injuries by $2010 .^{1}$ Prominent within the strategy is a plan to reduce deaths and serious injuries in teenage drivers. Drivers aged 17-21 years make up $7 \%$ of licence holders but $13 \%$ of drivers involved in road traffic crashes resulting in injury. ${ }^{1}$ The government proposed to tackle the problem of teenage road deaths with driver education programmes in schools and colleges. Students aged 16 to 18 years were offered an education package developed by the Driving Standards Agency (DSA), the executive agency of the Department of Environment, Transport and the Regions (DETR) responsible for driving tests in Britain and funded from driving test fees. The DSA Schools Programme involves presentations by driving examiners about selecting a driving instructor, the theory and practical tests, and a range of road safety issues. ${ }^{2}$ In the year the policy was announced, driving examiners made 800 presentations to schools and colleges in Britain reaching 125,000 students. In December 2000, Mr Keith Hill, Parliamentary Under Secretary of
State for the DETR, announced an expansion of the programme to reach some 750,000 students. $^{3}$

Driver education, licensing and teenage road traffic crashes

Driver education has a long history as a road safety strategy and considerable effort has been given to evaluating its effectiveness. A major concern with driver education is that it might encourage teenagers to obtain a driving license and start driving sooner than they would in the absence of driver education. Because teenagers have a higher risk of road death and serious injury than any other age group, earlier licensing could offset any beneficial effect of driver education and increase the number of teenage road traffic crashes.

To quantify the effect of school driver education on licensing and road traffic crashes we conducted a systematic search for randomised controlled trials. The search strategy is available from the authors. A 1999 systematic review, including all studies with some form of no intervention comparison group had concluded that there was no evidence that driver education reduces motor vehicle crash involvement, 
and because the programmes encourage earlier licensing this may result in higher crash involvement for young drivers. ${ }^{4}$ We aimed to update this review in case any new controlled trials had become available. Because the 1998 review included ecological designs that may give biased estimates of effectiveness, we restricted our search to randomised-controlled trials. Three randomised-controlled trials were identified, including a total of 17,965 randomised participants, the details of which are shown in the table. ${ }^{5,6,7}$ The results confirm that driver education leads to early licensing. They provide no evidence that driver education reduces road crash involvement, and suggest that it may lead to a modest but potentially important increase in the proportion of teenagers involved in traffic crashes.

The three trials of driver education were conducted in the Australia, USA and New Zealand, between 1982 and 1984, and it is important to ask whether their results can be generalised to the DSA Schools Programme in 2001. The DSA programme is much less intensive, the entire presentation lasting only 50 minutes, with no behind the wheel driver training and greater emphasis on taking the driving test. For driver education to be effective in reducing crash involvement, the effect of early licensing must be offset by improved driving skills. With its emphasis on the driving test, the DSA programme could easily increase licensing but with little or no impact on driving skills, potentially the worst combination from a road safety perspective. If the DSA programme increased the proportion of licensed teenagers by just $2 \%$, then an additional 27 teenagers might be killed or seriously injured each year as a result of this road safety programme.

\section{Research in support of the DSA schools programme}

On announcing the decision to double the number of driver education programmes the Parliamentary Under Secretary of State for the DETR cited the evidence in support of the policy.

"It is also important to get road safety messages across to older children. Independent research has confirmed the value of the Driving Standard's Agency's schools programme - presentations by driving examiners about learning to drive and road safety generally. We are doubling the number of programmes this year to 1,500 , reaching some 750,000 students aged 16 to 18. Further increases will follow."

House of Commons Hansard Debates for 19 December 2000.

The British Institute of Traffic Education Research (BITER) carried out the research cited in Hansard. A survey was conducted of the "attitudes, knowledge and intended behaviour" of 947 teenage students at three schools, before, immediately after, and three months after a presentation by a DSA instructor. ${ }^{8}$ At three months, mean score for some of the attitude statements had shifted slightly toward supporting safer driving. There was no control group and the response rate to the survey was low at $36 \%$. Even if the results are valid, there is no reliable evidence that changes in selfreported knowledge and attitudes lead to changes in behaviour or reduced crash rates. There was no reference in the BITER report to the previous randomised controlled trials.

\section{Towards evidence based road safety}

Because we were concerned that the government's road safety strategy included an intervention that may increase teenage road traffic crashes, on January $10^{\text {th }} 2001$ we wrote to the Prime Minister asking that the policy be stopped. Our letter was forwarded to the Department of Education and Employment and the DETR for response. We also wrote to the Chancellor, arguing that driver education is a waste of the scarce resources for road safety, to the Secretary of State for Education asking that the programme be stopped, and to Her Majesty's Chief Inspector of Schools, asking that schools' participation in the DSA programme be audited. At the time of writing only Mike Tomlinson, Her Majesty's Chief Inspector of Schools, had replied. He did not share our concerns:

"While we have a common interest in the safety of young people, and indeed, safety on the roads, we do not necessarily concur with the view that you take of the Driving Standards Agency's initiative."

He argued that the results of previous randomised-controlled trials could not be generalised to the UK and cited the results of the BITER study in support of the DSA programme. 
"The article by Vernick et al is a survey of research (some from as long ago as the 1970's) into 'high school driver education' courses in the USA. The article indicates that, in some states, a full driving licence can be obtained as early as the age of 15.

The British Institute of Traffic Education Research (BITER) undertook an Evaluation of the DSA Schools Initiative in 1998. This lengthy report surveyed nearly a thousand students before, after and three months after DSA presentations. The findings indicate sustained improved attitudes to road safety and awareness of risks."

On $15^{\text {th }}$ January one of us (IR) had the opportunity to raise our concern with Lord Whitty, the Parliamentary Under Secretary of State for the DETR with responsibility for road safety. This meeting was for members of Road Peace - the national charity for road traffic victims -- of which IR is a Trustee, and was not in response to our letters. Lord Whitty also referred to the BITER report in support of the DSA schools programme but agreed to a meeting between DETR officials and ourselves to 'discuss methodology.'

\section{Evidence based policy: fact or fiction?}

If road safety policy is to be based on the best available research evidence there must be a greater understanding that study design has an important bearing on the validity of research findings. Efforts are also required to make the results of controlled trials of road safety interventions more accessible. Road safety databases have a limited range of indexing terms describing the study methodology, so that identification of studies with designs that reduce the likelihood of bias (e.g. controlled trials) is almost impossible. The final step towards evidence based policy will be political will to take evidence into account. In his letter of January $22^{\text {nd }}$ confirming a meeting with DETR officials, Lord Whitty wrote: "As you are aware we are keen to develop and promote evidence based policies to improve road safety." Unless school based driver education programmes are stopped this statement must be viewed with scepticism.

\section{Acknowledgements}

The authors thank Jon Vernick for sending copies of two of the randomised trials and Reinhard Wentz for his help with searching.

\section{Note}

A systematic review of school driver education will be published in the Cochrane Library where it will be regularly updated to take account of new data and comments from readers.

\section{References}

1. DETR. Tomorrow's roads: safer for everyone. The Government's road safety strategy and casualty reduction targets for 2010. Department of the Environment, Transport and the Regions: London, 2000.

\section{2. http://www.driving-tests.co.uk/}

3. House of Commons Hansard Debates for 19 December 2000.

4. Vernick JS, Guohua L, Ogaitis S, macKenzie EJ, Baker SP, Gielen AC. Effects of high school driver education on motor vehicle crashes, violations, and licensure. Am J Prev Med 1999;16(1S):40-6.

5. Strang PM, Deutsch KB, James RS, Manders SM. A Comparison of On-Road and Off-Road Driver Training. Victoria, Australia: Road Safety and Traffic Authority: 1982.

6. Stock JR, Weaver JK, Ray HW, Brink JR, Sadoff MG. Evaluation of Safe performance Secondary School Driver Education Curriculum Demonstration Project. Washington, DC: US Department of Transportation, National Highway Traffic Safety Administration; 1983.

7. Wynne-Jones JD, Hurst PM. The AA Driver Training Evaluation. Traffic Research Report No. 33. Ministry of Transport, Road Transport Division, Wellington, New Zealand: 1984.

8. Clayton $A B$, Lee $C$, Sudlow D E, Butler G, Lee T. Evaluation of the DSA Schools' Initiatives. British Institute of Traffic Education Research; Sept 1998 


\section{Correspondence}

lan Roberts

Cochrane Injuries Group

Public Health Intervention Research Unit

London School of Hygiene \& Tropical

Medicine

49-51 Bedford Square

London WC1B 3DP
Phone: 02072994748

Fax: 02072994684

E-mail: ian.roberts@Ishtm.ac.uk

\section{Original source of publication}

The Lancet, Vol 358, July 212001 , pp.230-32 


\begin{tabular}{|c|c|c|c|c|c|}
\hline Reference & Study design & Participants & Intervention & Outcomes & Results \\
\hline $\begin{array}{l}\text { Strang, } 1982 \\
\text { (Australia) }\end{array}$ & $\begin{array}{l}\text { Cluster randomised-controlled trial: } \\
\text { Once an organisation had accepted an } \\
\text { invitation to participate in the project it } \\
\text { was assigned at random to one of the } \\
\text { four experimental conditions. Random } \\
\text { allocation was done within strata (state } \\
\text { high schools, secondary technical } \\
\text { schools, catholic secondary schools, } \\
\text { independent secondary schools, } \\
\text { employers of young men, technical } \\
\text { colleges). }\end{array}$ & $\begin{array}{l}779 \text { males aged } 17 \text { to } 19 \text { years holding a } \\
\text { current learner permit and living in the } \\
\text { Melbourne area. }\end{array}$ & $\begin{array}{l}\text { One of three driver education } \\
\text { courses or a control group. } \\
\text { Participants in each of the } \\
\text { three trained groups received } \\
5 \text { hours 'behind the wheel' } \\
\text { training. Participants in the } \\
\text { control group were given no } \\
\text { formal training but were } \\
\text { allowed to arrange driving } \\
\text { practice or lessons during the } \\
\text { course of the study. }\end{array}$ & $\begin{array}{l}\text { Proportion of participants } \\
\text { having at least one accident } \\
\text { since being licensed }\end{array}$ & $\begin{array}{l}\text { Driver education 230/549 (42\%) } \\
\text { Control 80/193 (42\%) }\end{array}$ \\
\hline $\begin{array}{l}\text { Stock, } 1983 \\
\text { (USA) }\end{array}$ & $\begin{array}{l}\text { Randomised controlled trial: Students } \\
\text { were assigned to one of the three } \\
\text { groups using a stratified random } \\
\text { sampling plan. Stratification was based } \\
\text { on parents' socio-economic status, } \\
\text { student grade point average and sex. } \\
\text { Allocation was by central computer. }\end{array}$ & $\begin{array}{l}16,338 \text { high school students, who } \\
\text { applied for driver education in DeKalb } \\
\text { County high schools and who said that } \\
\text { they wanted to get their license as soon } \\
\text { as possible. }\end{array}$ & $\begin{array}{l}\text { 1. The Safe Performance } \\
\text { Curriculum (SPC): } 72 \\
\text { hours of formal } \\
\text { instruction and testing } \\
\text { 2. The Pre-Driver } \\
\text { Licensing Curriculum } \\
\text { (PDL): the minimum } \\
\text { training required to pass } \\
\text { the driving test, involved } \\
24 \text { hours of formal } \\
\text { instruction and testing. } \\
\text { 3. Control group: No } \\
\text { formal driver education } \\
\text { apart from any teaching } \\
\text { provided by their parents } \\
\text { or by private driver } \\
\text { training schools. }\end{array}$ & $\begin{array}{l}\text { The number of students } \\
\text { who have been licensed } \\
\text { before or within six months } \\
\text { of their sixteenth birthday } \\
\text { or the course completion } \\
\text { date whichever is the later. } \\
\text { The number of students } \\
\text { who were involved as a } \\
\text { driver in one or more } \\
\text { accidents }\end{array}$ & $\begin{array}{l}\text { Licensing } \\
\text { 1. SPC: } 4829(88.4 \%) \\
\text { OR= } 1.05(1.03 \text { to } 1.06) \\
\text { 2. PDL: } 4681(86.2 \%) \\
\text { OR= } 1.02(1.01 \text { to } 1.04) \\
\text { 3. Control: } 4588(84.3 \%) \\
\text { Accidents } \\
\text { 1. SPC: } 1563(28.6 \%) \\
\text { OR= } 1.07(1.01 \text { to } 1.14) \\
\text { 2. PDL: } 1437(26.5 \%) \\
\text { OR= } 0.99(0.93 \text { to } 1.05) \\
\text { 3. Control: } 1456(26.7 \%)\end{array}$ \\
\hline
\end{tabular}




\begin{tabular}{|c|c|c|c|c|c|}
\hline Reference & Study design & Participants & Intervention & Outcomes & Results \\
\hline $\begin{array}{l}\text { Wynne-Jones, } 1984 \\
\text { (New Zealand) }\end{array}$ & $\begin{array}{l}\text { Randomised controlled trial: Students } \\
\text { were selected by ballot within each } \\
\text { school, stratified by sex, either to attend } \\
\text { the driving course or to be left to their } \\
\text { own devices to learn to drive. }\end{array}$ & $\begin{array}{l}848 \text { secondary school students aged } 15 \\
\text { to } 18 \text { years from } 23 \text { schools in } \\
\text { Christchurch. About } 60 \text { students were } \\
\text { deleted from the experiment because of } \\
\text { failure to complete correctly the } \\
\text { enrolment form, filling out more than } \\
\text { one form, or being selected on some } \\
\text { other non-random basis. }\end{array}$ & $\begin{array}{l}\text { The Automobile Association } \\
\text { driver training programme, } \\
\text { largely undertaken in school } \\
\text { hours, consists of } 8 \text { hrs behind } \\
\text { the wheel instruction, } 8 \text { hrs as } \\
\text { a passenger while another } \\
\text { student is being instructed, } \\
\text { eight lectures on road traffic } \\
\text { law and correct attitudes and } \\
\text { two lectures on motor } \\
\text { mechanics. At the end of the } \\
\text { programme the students take } \\
\text { the driving test. }\end{array}$ & $\begin{array}{l}\text { Number of days from trial } \\
\text { enrolment until driving } \\
\text { license obtained (licensing } \\
\text { delay). } \\
\text { Accidents by self report } \\
\text { Accidents by official record }\end{array}$ & $\begin{array}{l}\text { Licensing delay } \\
\text { Males experimental = } 111 \text { days } \\
\text { Males control = } 300 \text { days } \\
\mathrm{T}=7.190 \text { ( }<0.001) \\
\text { Females experimental = } 105 \text { days } \\
\text { Females control = } 415 \text { days } \\
\mathrm{T}=9.881 \text { ( }<0.001) \\
\text { Accidents (self report) } \\
\text { Male experimental } 29 / 206(14 \%) \\
\text { Male control } 19 / 119(16 \%) \\
\text { OR=0.86 (0.46 to } 1.62) \\
\text { Female experimental } 53 / 355(15 \%) \\
\text { Female control } 5 / 108(5 \%) \\
\text { OR=3.62 (1.41 to 9.29) } \\
\text { Accidents (official records) } \\
\text { Male experimental } 4 / 206(2 \%) \\
\text { Male control } 7 / 119(6 \%) \\
\text { OR=0.32 (0.09 to } 1.11) \\
\text { Female experimental } 4 / 355(1 \%) \\
\text { Female control } 2 / 108(2 \%) \\
\text { OR=0.60 ( } 0.11 \text { to } 3.34)\end{array}$ \\
\hline
\end{tabular}

